roidism. As Asher's graphic term "myxoedematous madness" 15 indicates, the earlier descriptions based on clinically obvious cases of myxoedema ${ }^{1617}$ stressed the occurrence of florid psychotic manifestations, depression being mentioned only parenthetically. In our relatively unselected cases depression totally overshadowed manifestations of this type.

We express our gratitude to staff of the service section of the division of chemical pathology and staff of the radioisotope service for performance of the thyroid function tests.

Requests for reprints should be sent to Dr. H. M. Hodkinson.

\section{References}

${ }^{1}$ Jeffreys, P. M., Age and Ageing, 1972, 1, 33.
${ }^{2}$ Hodkinson, H. M., and Jeffreys, P. M., British Medical fournal, 1972, 4, 536.

3 Jefferys, P. M., et al., Lancet, 1972, 1, 924

4 Hall, R., et al., British Medical fournal, 1971, 1, 582.

5 Hall, R., et al., British Medical fournal, 1971, 1, 582.

5 Denham, M. J., and Himsworth, R. L., Age and Ageing

6 Hodkinson, H. M., Gerontologia Clinica, 1974, 16, 175.

7 Denham, J. J., and Jeffreys, P. M., Modern Geriatrics, 1972, 2, 275.

Denham, M. J., personal communication, 1974.

${ }^{9}$ Kimble, S. T., and Stieglitz, E. J., Geriatrics, 1952, 7, 20.

10 Werner, S. C., The Thyroid, N.Y., Harper and Row, 1962.

11 Lloyd, W. H., and Goldberg, I. J. L., British Medical fournal, 1961, 2, 1256.

12 Hills, W. C., Geriatrics, 1968, 23, 124

13 Medical fournal of Australia, 1972, 2, 780

14 Taylor, B. B., Thomson, J. A., and Caird, F. I., Age and Ageing, 1974, 3,122 .

15 Asher, R., British Medical fournal, 1949, 2, 555.

${ }^{16}$ Committee of the Clinical Society, Transactions of the Clinical Society of London, 1888, 21, Suppl.

17 Akelaitis, A. J. E., fournal of Nervous and Mental Disease, 1936, 83, 22.

\title{
Chlormethiazole in Treatment of Status Epilepticus
}

\author{
P. K. P. HARVEY， T. W. HIGENBOTTAM， L. LOH
}

British Medical fournal, 1975, 2, 603-605

\begin{abstract}
Summary
Chlormethiazole (Heminevrin) was successful in controlling fits in seven out of nine episodes of intractable status epilepticus. It was administered as a constant intravenous injection at rates of up to $0.7 \mathrm{~g} / \mathrm{h}$. No serious side effects were encountered, and the drug deserves wider recognition as a useful therapeutic agent in the management of status epilepticus.
\end{abstract}

\section{Introduction}

The management of status epilepticus has been transformed in recent years by the introduction of intravenous diazepam and thiopentone, which have largely replaced parenterally administered phenytoin, phenobarbitone, and paraldehyde. Nevertheless, some patients with status epilepticus fail to respond to these drugs. We have found chlormethiazole (Heminevrin) to be valuable in these cases. We report here its use in nine episodes of status epilepticus in eight patients seen over two years.

Chlormethiazole is a derivative of the thiazole nucleus of thiamine (vitamin $B_{1}$ ). It has anticonvulsant and sedative properties $^{1}$ and has been used in the management of acute alcohol withdrawal, ${ }^{2}$ toxaemia of pregnancy, ${ }^{3}$ and status epilepticus. ${ }^{1}$ It may be given intravenously or orally, but because it has a half life of 46 minutes it should be given either by continuous intravenous infusion or at frequent intervals when prescribed orally. It is free from serious side effects and has little cardiorespiratory depressant action in therapeutic doses, ${ }^{4}$ though apnoea has been reported in a child after an excessive dose. ${ }^{1}$

Batten Unit, National Hospital, Queen Square, London WC1N 3BG P. K. P. HARVEY, M.B., M.R.C.P., Senior Registrar (Now Consultant Neurologist, Whittington, Royal Northern, and Chace Hospitals, London)

T. W. HIGENBOTTAM, M.B., M.R.C.P., Senior House Officer (Now Medical Registrar, Guy's Hospital, London)

L. LOH, M.B., F.F.A., R.C.s., Consultant Anaesthetist

\section{Patients}

The eight patients studied (three men and five women, aged from 19 to 67) were admitted to the Intensive Care Unit at the National Hospital, Queen Square, in "refractory" status epilepticus, one patient being admitted twice within six months. The clinical details of the patients are summarized in table I. Seven of them were in convulsive status epilepticus and one (case 6) was in focal motor status. Three had symptomatic epilepsy. One (case 1) had a progressive, diffuse encephalopathy of unknown aetiology which led ultimately to her death. Another (case 6) had an infantile hemiplegia. Case 7 was that of an alcoholic patient in whom status epilepticus was precipitated by a left hemisphere cerebrovascular accident. Contrast radiography showed no abnormality in the remaining five patients. Five out of the nine episodes of status were preceded by an alteration in the patient's antiepileptic drug therapy.

\section{Initial Treatment}

Before admission each patient had received diazepam (up to $20 \mathrm{mg}$ intravenously as a bolus) and four had also been given intramuscular paraldehyde. Seizure activity during admission was assessed by clinical observation, E.E.G. sampling, and continuous respiratory monitoring. Previously administered anticonvulsant drugs were continued throughout the whole period of status epilepticus.

After admission the first drug given in all cases was diazepam at the rate of $8 \mathrm{mg} / \mathrm{h}$ in a continuous intravenous infusion (table II). In five cases the dose was increased to $15 \mathrm{mg} / \mathrm{h}$. A higher dose caused respiratory depression without inhibiting seizures. In cases 2 and 3 doses up to $30 \mathrm{mg} / \mathrm{h}$ were tolerated but fits continued. Diazepam controlled status epilepticus in case 1 only by steadily increasing the dose to $60 \mathrm{mg} / \mathrm{h}$ over a period of seven weeks. Intravenous infusion of thiopentone at the rate of $125 \mathrm{mg} / \mathrm{h}$ was substituted for diazepam in cases 1 and 2. Both patients developed respiratory depression and needed assisted ventilation, one for four weeks and the other for nine days. Thiopentone controlled status in both cases but fits recurred if the dose was reduced.

\section{Chlormethiazole Treatment}

After diazepam or thiopentone had been stopped chlormethiazole in a solution of $0.8 \mathrm{~g} / 100 \mathrm{ml}$ was given by continuous 
TABLE I-Clinical Details of 9 Cases of Status Epilepticus Seen in 8 Epileptics. Cases $4 a$ and $4 b$ Represent Separate Episodes in Same Patient

\begin{tabular}{|c|c|c|c|c|c|c|c|c|}
\hline \multirow[b]{2}{*}{$\begin{array}{l}\text { Case } \\
\text { No. }\end{array}$} & \multirow[b]{2}{*}{ Sex } & \multirow[b]{2}{*}{ Age } & \multirow[b]{2}{*}{$\begin{array}{l}\text { Age at } \\
\text { Onset }\end{array}$} & \multicolumn{3}{|c|}{ Epilepsy } & \multicolumn{2}{|c|}{ Status Epilepticus } \\
\hline & & & & Type & $\begin{array}{l}\text { Underlying } \\
\text { Lesion }\end{array}$ & $\begin{array}{l}\text { Previous Drug } \\
\text { Therapy } \\
\text { (Daily Dose) }\end{array}$ & $\begin{array}{l}\text { Precipitating } \\
\text { Factor }\end{array}$ & $\begin{array}{c}\text { Duration before } \\
\text { Admission } \\
\text { (Hours) }\end{array}$ \\
\hline 1 & F. & 32 & 32 & $\begin{array}{l}\text { Motor focal } \\
\text { and grand mal }\end{array}$ & $\begin{array}{l}\text { Degenerative } \\
\text { disease, unknown }\end{array}$ & $\begin{array}{l}\text { Phenobarbitone } 180 \mathrm{mg} \text {, } \\
\text { phenytoin } 600 \mathrm{mg}\end{array}$ & $\begin{array}{l}\text { Progression of } \\
\text { disease }\end{array}$ & $\begin{array}{c}72 \\
\text { (intermittent) }\end{array}$ \\
\hline 2 & M. & 28 & 11 & Temporal lobe & Unknown & $\begin{array}{l}\text { Phenobarbitone } 240 \mathrm{mg} \text {, } \\
\text { phenytoin } 300 \mathrm{mg} \text {, } \\
\text { ethosuximide } 750 \mathrm{mg}\end{array}$ & $\begin{array}{l}\text { Stopping } \\
\text { ethosuximide }\end{array}$ & 12 \\
\hline 3 & F. & 22 & 19 & Temporal lobe & Unknown & Phenobarbitone $180 \mathrm{mg}$, & Unknown & 18 \\
\hline $4 \mathrm{a}$ & F. & 29 & 3 & Grand mal & Unknown & Phenobarbitone $90 \mathrm{mg}$, & Failure to take & 18 \\
\hline $4 b$ & F. & 29 & 3 & Grand mal & Unknown & $\begin{array}{l}\text { phenytoon } 300 \mathrm{mg} \\
\text { Phenobarbitone } 90 \mathrm{mg} \text {, }\end{array}$ & $\begin{array}{l}\text { drugs } \\
\text { Failure to take }\end{array}$ & 12 \\
\hline 5 & F. & 23 & 7 & Grand mal with & Unknown & Primidone, $750 \mathrm{mg}$, & Unknown & 24 \\
\hline 6 & M. & 34 & 20 & $\begin{array}{l}\text { tocal features } \\
\text { Focal motor }\end{array}$ & Cortical & $\begin{array}{l}\text { phenytorn } 300 \mathrm{mg} \\
\text { Primidone } 750 \mathrm{mg},\end{array}$ & $\begin{array}{l}\text { Failure to take } \\
\text { drugs }\end{array}$ & 72 \\
\hline 7 & M. & 67 & 67 & $\begin{array}{l}\text { Grand mal with } \\
\text { focal features }\end{array}$ & Alcoholic & $\begin{array}{c}\text { Phenobarbitone } 180 \mathrm{mg} \text {, } \\
\text { phenytoin } 300 \mathrm{mg}\end{array}$ & $\begin{array}{l}\text { Cerebrovascular } \\
\text { accident }\end{array}$ & 96 \\
\hline 8 & F. & 16 & 3 & $\begin{array}{l}\text { Grand mal with } \\
\text { petit mal }\end{array}$ & Unknown & $\begin{array}{l}\text { Phenobarbitone } 180 \mathrm{mg} \text {, } \\
\text { phenytoin } 450 \mathrm{mg} \text {, } \\
\text { benuride } 400 \mathrm{mg}\end{array}$ & $\begin{array}{l}\text { Reduction in drug } \\
\text { therapy }\end{array}$ & 12 \\
\hline
\end{tabular}

TABLE II-Drug Treatment of 9 Cases of Status Epilepticus in 8 Patients Admitted to Hospital. Cases $4 a$ and $4 b$ Represent Separate Episodes in Same Patient

\begin{tabular}{|c|c|c|c|c|c|c|c|c|}
\hline \multirow[b]{2}{*}{$\begin{array}{l}\text { Case } \\
\text { No. }\end{array}$} & \multicolumn{3}{|c|}{ Initial } & \multicolumn{5}{|c|}{ Chlormethiazole } \\
\hline & Drug (I.V.)* & $\underset{(\mathrm{g} / 24 \mathrm{~h})}{\operatorname{Maximum} \text { Dose }}$ & $\underset{\text { (Days) }}{\text { Duration }}$ & Dose Rate & $\begin{array}{c}\text { Duration } \\
\text { (Days) }\end{array}$ & Effect on Fits & $\begin{array}{l}\text { Additional } \\
\text { Treatment }\end{array}$ & Outcome \\
\hline 1 & $\begin{array}{l}\text { (1) Diazepam } \\
\text { (2) Thiopentone }\end{array}$ & $\begin{array}{l}1.44 \\
3.00\end{array}$ & $\begin{array}{l}49 \\
28\end{array}$ & $\begin{array}{l}\text { (1) } 0.5 \mathrm{~g} / \mathrm{h}(\mathrm{I} . \mathrm{V} .)^{*} \\
\text { (2) } 1 \mathrm{~g} / 3 \mathrm{~h} \text { (oral) }\end{array}$ & $\begin{array}{l}21 \\
21\end{array}$ & Ceased & $\begin{array}{l}\text { Primidone } 750 \mathrm{mg}, \\
\text { phenytoin } 400 \mathrm{mg}, \\
\text { carbamezapine } \\
600 \mathrm{mg}\end{array}$ & Died \\
\hline 2 & $\begin{array}{l}\text { (1) Diazepam } \\
\text { (2) Thiopentone }\end{array}$ & $\begin{array}{l}0.72 \\
3 \cdot 00\end{array}$ & $\begin{array}{l}1 \\
9\end{array}$ & $0.7 \mathrm{~g} / \mathrm{h}$ (I.V.) & 7 & $\begin{array}{l}\text { Ceased within } \\
24 \text { hours }\end{array}$ & $\begin{array}{l}\text { Phenytoin } 300 \mathrm{mg} \text {, } \\
\text { carbamezapine } 800 \\
\text { mg, ethosuximide }\end{array}$ & $\begin{array}{l}\text { Fit free } \\
\text { (3 months) }\end{array}$ \\
\hline 3 & Diazepam & 0.72 & 4 & $0.5 \mathrm{~g} / 3 \mathrm{~h}$ (oral) & 3 & $\begin{array}{l}\text { Ceased within } \\
3 \text { hours }\end{array}$ & $\begin{array}{l}\text { Phenobarbitone } \\
120 \mathrm{mg} \text {, phenytoin } \\
600 \mathrm{mg} \text {, carbamazepine }\end{array}$ & Fit free \\
\hline $4 a$ & Diazepam & 0.36 & 2 & $\begin{array}{l}\text { (1) } 0.5 \mathrm{~g} / \mathrm{h} \text { (I.V.) } \\
\text { (2) } 0.75 \mathrm{~g} / 2 \mathrm{~h} \text { (oral) }\end{array}$ & $\begin{array}{l}1 \\
3\end{array}$ & $\begin{array}{l}\text { Ceased within } \\
6 \text { hours }\end{array}$ & $\begin{array}{l}\text { Phenobarbitone } 90 \\
\text { mg, phenytoin } 450 \\
\text { mg }\end{array}$ & $\begin{array}{l}\text { Fit free } \\
\text { (pheneturide } \\
600 \mathrm{mg} \\
\text { substituted }\end{array}$ \\
\hline $4 \mathrm{~b}$ & Diazepam & $0 \cdot 36$ & $\begin{array}{c}6 \\
\text { hours }\end{array}$ & $0.5 \mathrm{~g} / \mathrm{h}$ (I.V.) & 1 & $\begin{array}{l}\text { Ceased within } \\
1 \text { hour }\end{array}$ & $\begin{array}{l}\text { Phenobarbitone } 90 \\
\text { mg, pheneturide }\end{array}$ & $\begin{array}{l}\text { for phenytoin) } \\
\text { Fit free }\end{array}$ \\
\hline 5 & Diazepam & $0 \cdot 36$ & 3 & $0.5 \mathrm{~g} / \mathrm{h}$ (I.V.) & 4 & $\begin{array}{l}\text { Ceased within } \\
3 \text { hours, relapsed } \\
\text { after } 4 \text { days }\end{array}$ & $\begin{array}{l}\text { Primidone } 750 \mathrm{mg}, \\
\text { phenytoin } 300 \mathrm{mg}, \\
\text { sodium valproate } 3 \mathrm{~g}\end{array}$ & 3-4 fits/month \\
\hline 6 & Diazepam & 0.36 & $\begin{array}{l}18 \\
\text { hours }\end{array}$ & $0.5 \mathrm{~g} / \mathrm{h}$ (I.V.) & $\begin{array}{l}18 \\
\text { hours }\end{array}$ & $\begin{array}{l}\text { Ceased within } \\
1 \text { hour }\end{array}$ & $\begin{array}{l}\text { Primidone } 1 \mathrm{~g}, \\
\text { phenytoin } 800 \mathrm{mg}\end{array}$ & $\begin{array}{l}\text { Fit free on } \\
\text { previous therapy } \\
\text { (table 1) }\end{array}$ \\
\hline 7 & Diazepam & 0.36 & 1 & $0.5 \mathrm{~g} / \mathrm{h}$ (I.V.) & 2 & $\begin{array}{l}\text { Ceased within } \\
1 \text { hour }\end{array}$ & $\begin{array}{l}\text { Phenobarbitone } 90 \\
\text { mg, phenytoin } 300\end{array}$ & Fit free \\
\hline 8 & Diazepam & $0 \cdot 36$ & 3 & $0.5 \mathrm{~g} / \mathrm{h}(\mathrm{I} . \mathrm{V})$. & 5 & $\begin{array}{l}\text { Ceased for } 4 \text { days, } \\
\text { then relapsed }\end{array}$ & $\begin{array}{l}\text { mg } \\
\text { Primidone } 1 \mathrm{~g}, \\
\text { phenytoin } 500 \mathrm{mg}, \\
\text { ethosuximide } 1 \mathrm{~g}\end{array}$ & Fit free \\
\hline
\end{tabular}

* I.V. = Continuous intravenous infusion.

intravenous infusion at the rate of $500 \mathrm{ml}$ over six to eight hours $(0.7 \mathrm{~g}-0.5 \mathrm{~g} / \mathrm{h})$ to seven of the eight patients. The eighth (case 3 ) was given chlormethiazole $0.5 \mathrm{~g}$ every three hours by mouth (table II).

\section{Results of Chlormethiazole Treatment}

Seizures stopped in all patients within six hours of starting chlormethiazole (table II), but in cases 1 and 2 it had to be continued for three weeks since any reduction in the rate of infusion precipitated further fits. Assisted ventilation was not needed in either case when chlormethiazole was substituted for thiopentone. After three weeks, chlormethiazole $1 \mathrm{~g}$ three-hourly by mouth was substituted for intravenous therapy in case 1 and the patient remained free from fits until she died. One patient (case 4 a) was successfully controlled on intravenous chlormethiazole but developed a severe thrombophlebitis after 24 hours. Treatment was changed to chlormethiazole $0.75 \mathrm{~g}$ by mouth every two hours. She remained free from fits. In case 3 satisfactory control was achieved with chlormethiazole $0.5 \mathrm{~g}$ given through a nasogastric tube every three hours from the beginning. In cases 5 and 8 status epilepticus recurred after four and three days respectively, though the dose of chlormethiazole had not been changed. A bolus of chlormethiazole $1.6 \mathrm{~g}$ given over one hour had no effect in case 8 and the patient responded only to ethosuximide. The other patient (case 5) responded to thiopentone.

\section{SIDE EFFECTS}

None of the recognized side effects of chlormethiazole-namely, hypotension, depression of respiration, change in heart rate, bronchorrhoea, sneezing, and gastroentestinal disturbanceswere seen. Two patients developed thrombophlebitis at the site of infusion.

The effect of chlormethiazole on the level of consciousness was difficult to assess. All the patients except one (case 6) were in coma, but this lightened with the cessation of seizures. The drug caused drowsiness half an hour after administration when given orally (cases 1,3 , and 4 a). The patient (case 6 ) in focal motor status lost the drowsiness, dysarthria, and ataxia he had when on intravenous diazepam. There were no allergic pheno- 
mena, and haematological, renal, and liver function tests showed no abnormalities ascribable to chlormethiazole.

\section{Discussion}

Chlormethiazole proved a useful adjunct to the standard drug treatment in seven out of the nine episodes of status epilepticus in this study. The patients were highly selected in that they remained refractory to diazepam in adequate doses and three had failed to respond to intravenous thiopentone.

The value of intravenous diazepam in the immediate management of status epilepticus is well established. ${ }^{5} 6$ Its failure in some patients is probably due to inadequately maintained blood levels ${ }^{7}$ and is best overcome by the use of a continuous intravenous infusion. There remains, however, a small group of "refractory" patients. ${ }^{5}$ In these cases it had previously been our practice to give intravenous thiopentone as the drug of second choice. In subanaesthetic doses it can produce profound respiratory depression ${ }^{8}$ and in our experience the patient often needs assisted ventilation. Thus an effective alternative to diazepam is needed which is less apt than thiopentone to cause respiratory depression.

There are several reports of the efficacy of intravenous chlormethiazole in status epilepticus. ${ }^{9-12}$ In all except one doses of between $1.2 \mathrm{~g}$ and $3 \mathrm{~g}$ were given as a bolus and repeated at intervals of up to four hours. The reports are uniformly enthusiastic about the results, but varying degrees of depression of the level of consciousness and respiration were encountered. Houdart and Laborit ${ }^{11}$ used a similar regimen to ours $(0.3 \mathrm{~g} / \mathrm{h}$ as a constant infusion) and their patients did not have these side effects. More recently Manhire and Espir ${ }^{13}$ described a case of status epilepticus in which chlormethiazole controlled the fits but only at a rate of infusion $(1.5 \mathrm{~g} / \mathrm{h})$ which resulted in coma. ${ }^{14}$ We obtained satisfactory results with a rate of infusion of $0.5-$ $0.7 \mathrm{~g} / \mathrm{h}$ without serious impairment of consciousness or depression of respiration.

We think that chlormethiazole deserves wider recognition as an effective therapeutic agent in the management of status epilepticus.

We thank Dr. J. Newsom Davis for permission to report cases under his care and for his helpful advice, and the staff of the Drug Information Service of the National Hospital for their help.

Requests for reprints to Dr. Loh.

\section{References}

1 Lechat, P., Acta Psychiatrica et Neurologica Scandinavica, 1966, Suppl.,

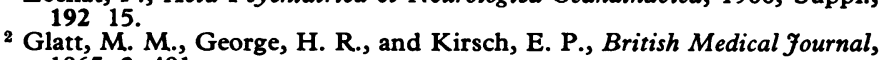
1965, 2 401.

3 Duffus, G. M., Tunstal, M. E., MacGallivray, I., Lancet, 1968, 1, 335. Wilson, J., Stephen, G. W., and Scott, D. B., British fournal of Anaesthesia, $1969,41,840$.

5 Parsonage, M. J., and Norris, J. W., British Medical Fournal, 1967, 3, 85. Nicol, C. F., Tutton, J. C., and Smith, B. H., Neurology (Minneap.), 1969, $19,332$.

' Booker, H. E., and Celesia, G. C., Archives of Neurology (Chicago), 1973, 29, 191.

8 Dundee, J. W., and Gray, R. C., British Medical fournal, 1967, 1, 362.

9. Poire, R., et al., Revue Neurologique, 1963, 108, 112.

10 Krause, G., Medizinische Klinik, 1964, 59, 1550.

11 Houdart, R., and Laborit, G., L'Encephale, 1965, 54, 440.

12 Laxenaire, M., Tridon, P., and Poire, P., Acta Psychiatrica et Neurologica Scandinavica, 1966, Suppl., 192, 87.

13 Manhire, A. R., and Espir, M., British Medical fournal, 1974, 3, 808.

14 Espir, M., Personal communication, 1974.

\title{
For Debate...
}

\section{Infant Leukaemias and Cot Deaths}

\author{
ALICE STEWART
}

British Medical fournal, 1975, 2, 605-607

\begin{abstract}
Summary
Infant leukaemias differ from childhood leukaemias in ways which suggest that when haemopoietic neoplasms combine fetal origins with rapid growth rates they prevent normal development of the reticuloendothelial system and thus cause the sudden death of apparently healthy babies (stillbirths or cot deaths). Cot deaths are commoner in boys and have a peak incidence during the first half of infancy-that is, during the period most affected by the switch from passive to active immunity. Babies born from July to December, who are intensively exposed to winter conditions from 1 to 5 months of age,
\end{abstract}

\footnotetext{
Department of Social Medicine, University of Birmingham,
Birmingham

ALICE STEW ART, M.D., F.R.C.P., Senior Research Fellow
}

are also at special risk. During this period more girls and more children born from January to June die of leukaemia; and within three months of birth an exceptionally high ratio of myeloid to lymphatic leukaemias has been replaced by a low ratio, which persists throughout childhood.

\section{Introduction}

Illnesses which might have proved fatal if they had not been treated with antibiotics are more often precursors of leukaemias than solid tumours. ${ }^{1}$ This observation was the starting point of an inquiry into causes of latent period deaths which eventually necessitated comparisons between infant leukaemias and cot deaths. ${ }^{2}$ Several observations suggested that both the childhood peak of leukaemia mortality and the small proportion of myeloid cases among childhood leukaemias ${ }^{3}$ might be artefacts caused by greater difficulty in recognizing infant than childhood leukaemias and the inclusion of more myeloid than lymphatic leukaemias among the infant cases. For example, most, if not all, childhood cancers have fetal origins. ${ }^{4}$ Secondly, we had 